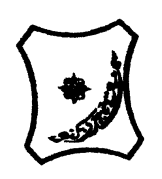

Bayero Journal of Pure and Applied Sciences, 10(1): 306 - 311

Received: February, 2017

Accepted: May, 2017

ISSN $2006-6996$

\title{
ON THE APLLICATION OF SINGLE SPECIE DYNAMIC POPULATION MODEL
}

\author{
${ }^{1}$ Iguda, A., ${ }^{1}$ Bala, S. and ${ }^{2}$ Gimba, B. \\ ${ }^{1}$ Department of Mathematics, Bayero University, Kano \\ ${ }^{2}$ School of Health Technology, Jahun. Ministry of Health Duste Jigawa State \\ ${ }^{*}$ Corresponding author: aiquda.mth@buk.edu.ng (08050701166)
}

ABSTRACT

The Method of mathematical models of Malthus and Verhults were applied on ten years data collected from Magaram Poultry Farm to determine the nature of population growth, population decay or constant growth in a Poultry Farm, and independent $t$-test as well as one way Anova were used to compare the predicted values and observed values in order to find out whether there is significant difference between the observed and predicted values using these two models.

Keywords: Birth rate, sustainable population, overcrowding, harvesting, independent $t$-test and one way Anova.

\section{INTRODUCTION}

It is feasible that we make reasonable assumptions in order to convert a real problem to mathematical one and also identify the most important variables and their mutual relationships. These assumptions and relations form the mathematical model and generally led to a mathematical problem of some sort, which is solved for the relevant variables using appropriate mathematical techniques.

Once a problem is solved, the solutions must be interpreted back in terms of the real problem and hence try to validate the model by checking if the theoretical solution is in good agreement with the observation from the real situation. If there is a reasonable agreement, then the model can be used either to give theoretical experiment, further observed phenomena to predict further results or to help in making decisions. However, if the agreement between the theoretical and the observed results is inadequate, we must return to our assumptions and deduce which of them need modifying or what additions should be made. The circle is then traversed once more to see if the new model gives adequate descriptions.

\section{Methodology}

The study was carried out in Magaram Poultry Farm located along Balangu road in Kafin Hausa Local Government area of Jigawa State, Nigeria. Established in November 2007 with a total population of seven thousands five hundred $(7,500)$ birds including cockerels and pullets purchased from Rano farm, located along Balangu road in Kafin Hausa Local Government area of Jigawa State.

\section{Data Collection}

Ten years data starting from 2001 to 2010 has been collected from Magaram Poultry farm and is presented below:

\begin{tabular}{ccccccccccc}
\multicolumn{1}{l}{ Table 1: Actual population of birds per year $\mathbf{2 0 0 1}$ to $\mathbf{2 0 1 0}$} \\
\hline $15^{\text {th }}$ Jan & 2001 & 2002 & 2003 & 2004 & 2005 & 2006 & 2007 & 2008 & 2009 & 2010 \\
\hline Population & 7,500 & 14,978 & 29,437 & 57,103 & 114,982 & 209,981 & 399,804 & 800,027 & 1,398484 & 2,584207 \\
\hline
\end{tabular}

\section{Data Analysis}

Two mathematical models were used to predict the number of birds from the actual number of birds and the results were analyzed by SPSS station software. The rate at which a population changes depends on at least three factors:

\section{Net Birth Rate for the Population}

The growth of a population depends on many factors and often depends on the way that one population interacts with other population.

We assume that a population changes linearly in proportion to the current value of the population. The constant of proportionality represents the net birth rate for the population and must account for a variety of factors such as:

i) The proportion of the population that will mate

ii) The number of offspring for each mating pair

iii) The proportion of the population that will die during the next period of time.

\section{Overcrowding and Scarcity of Resources}

We assume that a population is limited in size by resources such as the availability of food and land, we lump all of these factors into a single overcrowding term that will serve to decrease the population when it grows too large to be supported by the available resources.

\section{Harvesting}

The removal of a constant number of individuals from a population during each time period is known as harvesting or sometime fishing. Unregulated harvesting can lead a population to an end.। Population models that change according to the net birth rate of the current population leads to an exponential growth or decay of the population.

Model Analysis Using Malthus Method Suppose $\mathrm{N}$ is the number of birds and $t$ the independent variable, time. Let $\mathrm{N}(\mathrm{t})$ represent the number of birds (cockerel and pullets) at time $t$ in the interval $(t, t+\partial t)$. 
Bajopas Volume 10 Number 1 June, 2017

$\mathrm{N}(\mathrm{t})$ changes due to factors affecting population size such as mortality, harvesting, overcrowding, scarcity of resources and so on. Thus we have:

$$
\mathrm{N}(\mathrm{t}+\partial \mathrm{t})=\mathrm{N}(\mathrm{t})+\mathrm{bN}(\mathrm{t})-\mathrm{cN}(\mathrm{t})
$$

Where $\mathrm{b}$ is the birth rate and $\mathrm{c}$ is the mortality rate (or harvesting) and are assumed to be constant. (1) gives,

$$
\mathrm{N}(\mathrm{t}+\partial \mathrm{t})-\mathrm{N}(\mathrm{t})=\mathrm{bN}(\mathrm{t})-\mathrm{cN}(\mathrm{t})=\mathrm{N}(\mathrm{t})(\mathrm{b}-\mathrm{c})
$$

Thus $\quad \lim _{\partial t \rightarrow 0} \frac{N(t+\partial t)-N(t)}{\partial t}=\lim _{\partial t \rightarrow 0} N(t)(b-c)$

Eqn(3) gives $N^{\prime}(t)=\frac{d N}{d t}=D N(t)$ where $D=(b-c)$

From eqn(4) we have

$$
\int \frac{d N}{N(t)}=\int D d t \text {, hence } \log _{e} N(t)=D t+\mathrm{A} \text {, where A is a constant....... }
$$

Therefore, we have $N(t)=e^{D t+A}=e^{A} e^{D t}=E e^{D t}$, where $E=e^{A}$

When $\mathrm{t}=0$ we have the initial number of birds $\mathrm{N}_{\mathrm{o}}$. Therefore from (6) at $\mathrm{t}=0, \mathrm{~N}=\mathrm{N}_{\mathrm{o}}=\mathrm{E}$.

Hence, $N(t)=N_{o} e^{D t}$

\section{Validation of Malthus Model}

In the validation, the analysis of the formulation above would be interpreted to give the behavior of the mathematical model.

Based on the data in table 1 applying eqn(7), we have for the year 2001 at $t=0$,

$\mathrm{N}(0)=7500 \mathrm{e}^{0}=7,500$.

For the year 2002 that is at $\quad \mathrm{t}=1$ we have

$$
N(t)=7500 e^{D t} \Rightarrow 14978=7500 e^{D t}=7500 e^{D} \Rightarrow e^{D}=\frac{14978}{7500}=1.9971 \approx 2 .
$$

Therefore, $D=\log _{e} 2 \approx 0.7$, thus finaly we have

$$
N(t)=7500 e^{0.7 t}
$$

After calculating the value of $\mathrm{D}$ we now calculate the remaining values for $\mathrm{N}(\mathrm{t})$ at the corresponding time.

$$
\text { 2002, at } \mathrm{t}=1, \mathrm{~N}(1)=7,500 \mathrm{e}^{0.7}=15,103
$$

$$
\begin{gathered}
2003 \text {, at } \mathrm{t}=2, \mathrm{~N}(2)=7,500 \mathrm{e}^{0.7(2)}=7,500 \mathrm{e}^{1.4}=30,413.999 \approx 30,414 \\
2004 \text {, at }=3, \mathrm{~N}(3)=7,500 \mathrm{e}^{0.7(3)}=7,500 \mathrm{e}^{2.1}=61,246.2743 \approx 61,246 \\
2005 \text {, at }=4, \mathrm{~N}(4)=7,500 \mathrm{e}^{0.7(4)}=7,500 \mathrm{e}^{2.8}=123,334.8508 \approx 123,335 \\
2006 \text {, at }=5, \mathrm{~N}(5)=7,500 \mathrm{e}^{0.7(5)}=7,500 \mathrm{e}^{3.5}=248,365.8897 \approx 248,366 \\
2007 \text {, at }=6, \mathrm{~N}(6)=7,500 \mathrm{e}^{0.7(6)}=7,500 \mathrm{e}^{4.2}=500,147.4828 \approx 500,147 \\
2008 \text {, at }=7, \mathrm{~N}(7)=7,500 \mathrm{e}^{0.7(7)}=7,500 \mathrm{e}^{4.9}=1,007,173.348 \approx 1,007,173 \\
2009 \text {, at }=8, \mathrm{~N}(8)=7,500 \mathrm{e}^{0.7(8)}=7,500 \mathrm{e}^{5.6}=2,028,198.056 \approx 2,028,198 \\
2010 \text {, at }=9, \mathrm{~N}(9)=7,500 \mathrm{e}^{0.7(9)}=7,500 \mathrm{e}^{6.3}=4,084,289.326 \approx 4,084,289
\end{gathered}
$$

By the Malthus model we can now compare the calculated result with real one in table

Table 2: Predicted values against the actual number of birds (Malthus Model) $15^{\text {th }}$ Jan. Actual No. of Birds Predicted No. of Birds

$\begin{array}{lcc}2001 & 7,500 & \\ 2002 & 14,978 & 15,103 \\ 2003 & 29,437 & 30,414 \\ 2004 & 57,103 & 61,246 \\ 2005 & 114,982 & 123,355 \\ 2006 & 209,981 & 248,366 \\ 2007 & 399,804 & 500,147 \\ 2008 & 800,027 & 1,007,173 \\ 2009 & 1,398,485 & 2,028,198 \\ 2010 & 2,584,207 & 4,084,289\end{array}$

\section{Verhulst Model (Bounded Population)}

Verhulst population model is the modification of Malthus model. He assumed that there is upper limit denoted by $\mathrm{N}_{\infty}$ to the population, which, can be sustained. The change in population of size $\mathrm{N}$ with respect to change in time $t$ given by $d N / d t$ is, now assumed to be proportional to the current population level $\mathrm{N}$ and the fraction of the population resources still not utilized that is $\left(1-\mathrm{N} / \mathrm{N}_{\infty}\right)$. Thus we have $\frac{d N}{d t}=\gamma\left(1-\frac{N}{N_{\infty}}\right)$. 
$\frac{d N}{d t}=\gamma\left(1-\frac{N}{N_{\infty}}\right) \cdot \frac{d N}{N\left(1-\frac{N}{N_{\infty}}\right)}=\gamma d t$. To analyse the collected and tabulated data using Verhulst model, the

following assumptions were made.

Let $\quad \mathbf{N}_{\infty}$ be the maximum population of birds that can be sustained.

And the independent variable time be $t$

6.1 The Criteria for Estimating the Maximum Population of Birds

The initial population of birds $\mathrm{N}_{0}=7500$.

i) A bird takes $(16-18)$ weeks to start laying from the hatching day.

ii) A bird can lay up to 23 eggs in a month.

iii) A layed egg takes 21 days to hatch out.

iv) Egg takes 21 days to hatch out.

v) Thus in a year a bird will hatch $15 \times 3=45$ chickens approximately.

vi) Out of the total of 7500 birds we start with, 682 are cocks while 6, 818 are hens.

vii) This is base on the ratio of 1 cock to 10 hens that is, cock: hen 1: 10

viii) Hence, from 6750 hens we can get a maximum of $6,818 \times 45=306,810$ chickens in a year. Thus, $\mathrm{N}_{\infty}=$ 306,810

So, using the Verhulst model based on the data in table 1, we have:

$N(t)=\left(\frac{N_{\infty}}{1+\left(\frac{N_{\infty}-N_{o}}{N_{o}}\right) e^{-\gamma t}}\right)$ where as $t \rightarrow \infty, N \rightarrow N_{\infty}$. Taking $\mathrm{N}_{\infty}=306,810$.

For the year 2001, at $t=0, N(0)=\left(\frac{306810}{1+\left(\frac{306810-7500}{75000}\right) e^{-\gamma t}}\right)=\left(\frac{306810}{\frac{1027}{250}}\right)=\frac{306810 \times 250}{10227}=7,500$.

For the year 2002, at $t=1, N(1)=\left(\frac{306810}{1+\left(\frac{306810-7500}{7500}\right) e^{-\gamma t}}\right)=\left(\frac{306810}{1+\left(\frac{299310}{7500}\right) e^{-\gamma}}\right)=\left(\frac{306810}{1+(39.908) e^{-\gamma}}\right)$

$\Rightarrow 14978=\left(\frac{306810}{1+(39.908) e^{-\gamma}}\right) \Rightarrow 14978+14978(39.908) e^{-\gamma}=306,810 \Rightarrow 291382=597742.024 e^{-\gamma}$

$\Rightarrow e^{-\gamma}=\frac{291832}{597742.024}=0.488224 \Rightarrow \gamma \approx 0.717$. Hence, $N(t)=\left(\frac{306810}{1+(39.908) e^{-0.717}}\right)$

Therefore, for the year 2002, at $t=1, N(1)=\left(\frac{306810}{1+(39.908) e^{-0.717}}\right)=\left(\frac{306810}{20.4837}\right) \approx 14,978$

For the year 2003, at $t=2, N(2)=\left(\frac{306810}{1+(39.908) e^{-1.434}}\right)=\left(\frac{306810}{10.5122}\right) \approx 29.186$

For the year 2004, at $t=3, N(3)=\left(\frac{306810}{1+(39.908) e^{-2.151}}\right)=\left(\frac{306810}{5.6440}\right) \approx 54.360$

For the year 2005, at $t=4, N(4)=\left(\frac{306810}{1+(39.908) e^{-2.868}}\right)=\left(\frac{306810}{3.267}\right) \approx 93.912$

For the year 2006, at $t=5, N(5)=\left(\frac{306810}{1+(39.908) e^{-3.585}}\right)=\left(\frac{306810}{2.1069}\right) \approx 145.622$

For the year 2007, at $t=6, N(6)=\left(\frac{306810}{1+(39.908) e^{-4.302}}\right)=\left(\frac{306810}{1.5404}\right) \approx 199.176$

For the year 2008 , at $t=7, N(7)=\left(\frac{306810}{1+(39.908) e^{-5.019}}\right)=\left(\frac{306810}{1.2638}\right) \approx 242.768$ 
Bajopas Volume 10 Number 1 June, 2017

$$
\begin{aligned}
& \text { For the year } 2009 \text {, at } t=8, N(8)=\left(\frac{306810}{1+(39.908) e^{-5.736}}\right)=\left(\frac{306810}{1.1289}\right) \approx 271.778 \\
& \text { For the year } 2010 \text {, at } t=9, N(9)=\left(\frac{306810}{1+(39.908) e^{-6.453}}\right)=\left(\frac{306810}{1.0629}\right) \approx 288,654
\end{aligned}
$$

Table 3.0: Predicted value against the actual number of birds (Verhults Model)

\begin{tabular}{ccc}
\hline $15^{\text {th }}$ Jan. & Actual No. of Birds & Predicted No. of Birds \\
\hline 2001 & 7,500 & \\
2002 & 14,978 & 14,978 \\
2003 & 29,437 & 29,186 \\
2004 & 57,103 & 54,360 \\
2005 & 114,982 & 93,912 \\
2006 & 209,981 & 145,622 \\
2007 & 399,804 & 199,176 \\
2008 & 800,027 & 242,768 \\
2009 & $1,398,485$ & 271,778 \\
2010 & $2,584,207$ & 288,654 \\
\hline
\end{tabular}

Tables of statistical Analysis

OBSVSPREDMALTM

\begin{tabular}{ccccc}
\hline FACTORS & $\mathrm{N}$ & Mean & Std. Deviation & Std. Error Mean \\
\hline OBSERVE & 10 & 555650.4000 & 840875.41446 & 265908.15381 \\
PREDVMALM & 9 & 899810.1111 & 1362645.88312 & 454215.29437 \\
\hline
\end{tabular}

Table 4.0: Group statistics

\begin{tabular}{|c|c|c|c|c|c|c|c|c|}
\hline \multicolumn{2}{|c|}{$\begin{array}{l}\text { Levene's Test of } \\
\text { Equality of } \\
\text { Variance }\end{array}$} & \multicolumn{7}{|c|}{ t-test of Equality of Means } \\
\hline \multirow[t]{2}{*}{$\mathbf{F}$} & \multirow[t]{2}{*}{ Sig. } & \multirow[t]{2}{*}{$\mathrm{T}$} & \multirow[t]{2}{*}{$d f$} & \multirow{2}{*}{$\begin{array}{l}\text { Sig. } \\
(2- \\
\text { tailed) }\end{array}$} & \multirow{2}{*}{$\begin{array}{c}\text { Mean } \\
\text { Difference }\end{array}$} & \multirow{2}{*}{$\begin{array}{l}\text { Std. Error } \\
\text { Difference }\end{array}$} & \multicolumn{2}{|c|}{$\begin{array}{l}\text { 95\% confidence interval of the } \\
\text { Difference }\end{array}$} \\
\hline & & & & & & & Lower & Upper \\
\hline \multirow[t]{2}{*}{1.200} & .289 & -.670 & 17 & .512 & - & 513315.12454 & - & 738840.53498 \\
\hline & & -.654 & 13.060 & .525 & $\begin{array}{r}344159.71111 \\
- \\
344159.71111\end{array}$ & 526325.64056 & $\begin{array}{r}1427159.95720 \\
- \\
1480689.24935\end{array}$ & 792369.82713 \\
\hline
\end{tabular}
OBSVSPREDMALTM

Table 5.0: T-Test OBSVSPREDVERHM

\begin{tabular}{ccccc}
\hline FACTORS & $\mathrm{N}$ & Mean & Std. Deviation & Std. Error Mean \\
\hline OBSERVE & 10 & 555650.4000 & 840875.41446 & 265908.15381 \\
PREDVMALM & 9 & 148937.1111 & 106188.41128 & 35396.13709 \\
\hline
\end{tabular}

Table 6.0: Group statistics

\begin{tabular}{|c|c|c|c|c|c|c|c|c|}
\hline \multicolumn{2}{|c|}{$\begin{array}{l}\text { Levene's Test of } \\
\text { Equality of } \\
\text { Variance }\end{array}$} & \multicolumn{7}{|c|}{ t-test of Equality of Means } \\
\hline \multirow[t]{2}{*}{$\mathbf{F}$} & \multirow[t]{2}{*}{ Sig. } & \multirow[t]{2}{*}{$\mathrm{T}$} & \multirow[t]{2}{*}{$\mathrm{df}$} & \multirow{2}{*}{$\begin{array}{c}\text { Sig. } \\
(2- \\
\text { tailed })\end{array}$} & \multirow{2}{*}{$\begin{array}{c}\text { Mean } \\
\text { Difference }\end{array}$} & \multirow{2}{*}{$\begin{array}{l}\text { Std. Error } \\
\text { Difference }\end{array}$} & \multicolumn{2}{|c|}{$\begin{array}{l}\text { 95\% confidence interval of the } \\
\text { Difference }\end{array}$} \\
\hline & & & & & & & Lower & Upper \\
\hline \multirow[t]{2}{*}{9.154} & 0.008 & 1.437 & 17 & .169 & 406713.28889 & 283100.44509 & - & 1004003.01802 \\
\hline & & 1.516 & 9.318 & .163 & 406713.28889 & 268253.67245 & $\begin{array}{r}190576.44025 \\
- \\
196971.82444\end{array}$ & 1010398.40222 \\
\hline
\end{tabular}

OBSVSPREDVERHM 
Bajopas Volume 10 Number 1 June, 2017

Table 7.0: T-Test

PREDMALTMVSPREDVERHM

\begin{tabular}{ccccc}
\hline FACTORS & $\mathrm{N}$ & Mean & Std. Deviation & Std. Error Mean \\
\hline PREDVVERHM & 9 & 148937.1111 & 106188.41128 & 35396.13709 \\
PREDVMALM & 9 & 899810.1111 & 1362645.88312 & 454215.29437 \\
\hline
\end{tabular}

Table 8.0: Group statistics

PREDMALTMVSPREDVERHM

\begin{tabular}{|c|c|c|c|c|c|c|c|c|}
\hline \multicolumn{2}{|c|}{$\begin{array}{c}\text { Leven's Test of } \\
\text { Equality of } \\
\text { Variance }\end{array}$} & \multicolumn{7}{|c|}{ t-test of Equality of Means } \\
\hline \multirow{5}{*}{$\begin{array}{c}\mathbf{F} \\
9.257\end{array}$} & \multirow{4}{*}{$\begin{array}{l}\text { Sig. } \\
.008\end{array}$} & \multirow[t]{2}{*}{$\mathrm{T}$} & \multirow[t]{2}{*}{ df } & \multirow{2}{*}{$\begin{array}{l}\text { Sig. } \\
(2- \\
\text { tailed) }\end{array}$} & \multirow{2}{*}{$\begin{array}{c}\text { Mean } \\
\text { Difference }\end{array}$} & \multirow{2}{*}{$\begin{array}{l}\text { Std. Error } \\
\text { Difference }\end{array}$} & \multicolumn{2}{|c|}{$\begin{array}{l}\text { 95\% confidence interval of the } \\
\text { Difference }\end{array}$} \\
\hline & & & & & & & Lower & Upper \\
\hline & & - & 16 & .119 & & 455592.38379 & Lever & 214939.70867 \\
\hline & & 1.648 & & & 750873.00000 & & 1716685.70867 & \\
\hline & & $\begin{array}{c}- \\
1.648\end{array}$ & 8.097 & .137 & 750873.00000 & 455592.38379 & 1799280.62302 & 297534.62302 \\
\hline
\end{tabular}

Table 9.0: T-Test

PREDMALTMVSPREDVERHM

\begin{tabular}{|c|c|c|c|c|c|c|c|c|}
\hline & \multirow[t]{2}{*}{$\mathrm{N}$} & \multirow[t]{2}{*}{ Mean } & \multirow[t]{2}{*}{ Std. Deviation } & \multirow[t]{2}{*}{ Std. Error } & \multicolumn{2}{|c|}{$95 \%$ Confidence Interval for } & \multirow[t]{2}{*}{ Minimum } & \multirow[t]{2}{*}{ Maximum } \\
\hline & & & & & Lower Bound & Upp & & \\
\hline PREL & 9 & 11 & 28 & 709 & 67313.4726 & 50.7496 & 00 & .00 \\
\hline PREDVMALM & 9 & 899810.1111 & 1362645.88312 & 454215.29437 & -147612.2360 & 2.4582 & 15103.00 & $4.08 \mathrm{E}+006$ \\
\hline OBSV & 10 & 555650.4000 & 840875.41446 & 265908.15381 & -45875.6348 & 1157176.4348 & 7500.00 & $2.58 \mathrm{E}+006$ \\
\hline Total & 28 & 535543.8929 & 939891.96118 & 177622.88490 & 171091.8372 & 899995.9485 & 7500.00 & $4.08 \mathrm{E}+006$ \\
\hline
\end{tabular}

Table 10.0: Group Statistics

\begin{tabular}{|c|c|c|c|}
\hline Levene Statistic & $\mathrm{df} 1$ & $\mathrm{df} 2$ & Sig. \\
\hline 5.232 & 2 & 25 & 0.013 \\
\hline
\end{tabular}

Table 11.0: Levene Statistics
PREDMALTMVSPREDVERHM

\begin{tabular}{|c|c|c|c|c|c|}
\hline & Sum of Squares & df & Mean Square & $\mathrm{F}$ & Sig. \\
\hline Between Groups & 2543434849372.501 & 2 & 1271717424686.251 & 1.492 & .244 \\
Within Groups & 21308281415522.180 & 25 & 852331256620.887 & & \\
Total & 23851716264894.680 & 27 & & & \\
\hline
\end{tabular}

Table 12.0: Anova table

PREDMALTMVSPREDVERHM

\begin{tabular}{|c|c|c|c|c|}
\hline & Statistic $^{\mathrm{a}}$ & $\mathrm{df1}$ & $\mathrm{df2}$ & Sig. \\
\hline Brown-Forsythe & 1.477 & 2 & 13.396 & .263 \\
\hline
\end{tabular}

Asymptotically $\mathrm{F}$ distributed.

Table 13.0: Robust Tests of Equality of Means

PREDMALTMVSPREDVERHM

\begin{tabular}{|c|c|c|c|c|c|c|c|}
\hline & \multirow{2}{*}{ (I) FACTORS } & \multirow{2}{*}{ (J) FACTORS } & \multirow{2}{*}{$\begin{array}{c}\text { Mean Difference } \\
\text { (I-J) }\end{array}$} & \multirow{2}{*}{ Std. Error } & \multirow{2}{*}{ Sig. } & \multicolumn{2}{|c|}{ 95\% Confidence Interval } \\
\hline & & & & & & Lower Bound & Upper Bound \\
\hline \multirow{6}{*}{$\begin{array}{l}\text { Tukey } \\
\text { HSD }\end{array}$} & \multirow{2}{*}{ PREDVVERHM } & PREDVMALM & -750873.00000 & 435209.08299 & .216 & -1834904.8933 & 333158.8933 \\
\hline & & OBSV & -406713.28889 & 424189.34289 & .609 & -1463296.8816 & 649870.3038 \\
\hline & \multirow{2}{*}{ PREDVMALM } & PREDVVERHM & 750873.00000 & 435209.08299 & .216 & -333158.8933 & 1834904.8933 \\
\hline & & OBSV & 344159.71111 & 424189.34289 & .700 & -712423.8816 & 1400743.3038 \\
\hline & \multirow{2}{*}{ OBSV } & PREDVVERHM & 406713.28889 & 424189.34289 & .609 & -649870.3038 & 1463296.8816 \\
\hline & & PREDVMALM & -344159.71111 & 424189.34289 & .700 & -1400743.3038 & 712423.8816 \\
\hline \multirow{6}{*}{$\begin{array}{c}\text { Game } \\
\text { s- } \\
\text { Howel } \\
\text { I }\end{array}$} & \multirow{2}{*}{ PREDVVERHM } & PREDVMALM & -750873.00000 & 455592.38379 & .281 & -2049432.1282 & 547686.1282 \\
\hline & & OBSV & -406713.28889 & 268253.67245 & .327 & -1150986.4765 & 337559.8987 \\
\hline & \multirow{2}{*}{ PREDVMALM } & PREDVVERHM & 750873.00000 & 455592.38379 & .281 & -547686.1282 & 2049432.1282 \\
\hline & & OBSV & 344159.71111 & 526325.64056 & .793 & -1044785.3612 & 1733104.7834 \\
\hline & \multirow{2}{*}{ OBSV } & PREDVVERHM & 406713.28889 & 268253.67245 & .327 & -337559.8987 & 1150986.4765 \\
\hline & & PREDVMALM & -344159.71111 & 526325.64056 & .793 & -1733104.7834 & 1044785.3612 \\
\hline
\end{tabular}

Table 14.0: Post HOC test multiple comparison 
Bajopas Volume 10 Number 1 June, 2017

In this study we have predicted the number of birds from 2001 to 2010 using Malthus Model and Verhulst Model from the actual number of birds. Independent t-test was applied to compare the mean value of actual birds with mean value of predicted birds using Malthus Model under equal variance assumed. The significance level of Levene's Test for Equality of Variance was found to be greater than 0.05 indicating that there is no significant difference between the actual number of birds and predicted number of birds using Malthus Model since the $P_{\text {value }}$ of sign(2-tailed) is 0.512 greater than 0.05 .

Similar type of Independent T-test was also carried out under Equal Variance not assumed. The significance level of Levene's Test for Equality of Variance was found to be less than 0.05 indicating that there is no significant difference between the actual number of birds and predicted number birds using Verhulst Model since the $P_{\text {value }}$ of sign(2-tailed) is 0.169 greater than 0.05 .

The predicted values using the two models under Equal Variance assumed were also compared. The significance level of Levene's Test for Equality of Variance was found to be less than 0.05 indicating that there is no significant difference between the

\section{REFERENCES}

C. I. Krebs; Ecology-The exponential analysis of distribution and abundance, Harper and Row, New York, (1972)

C.S. Holing-Some Characteristics of Simple types of prediction and parasitism, Canada Entomologist, 91, (1959), 385

D. Ludwing, D. D. Jones and C.S Holing- Qualitative analysis of insect outbreaks systems: the spruce budworm and forest, J. Anim. Ecol. 47 (1978), 315

F. R. Oliver-Note on the logistic curve for human populations, Journal of Royal Statistical Society, 1982, 145.

Gotelli Nicholas, A primer of Ecology, Sinauer, (2001)..

J.J.O.Cannor, and E.F. Robertson- $h t t p: / / w w w-$ history.mCs.sc-andrews. ac.uk/Biographies/Verhulst.htm] (December, 1996) predicted number of birds using Malthus Model and Verhulst Model since the $P_{\text {value }}$ of sign(2-tailed) is 0.119 . Also we compared actual number of birds, predicted number of birds using Malthus Model and predicted number of birds using Verhulst Model by Analysis of Variance(Anova), from the Anova result, Levene Statistic will tell us wether to use Anova table or Robust Test of Equality of Means. In our own case, since the significance level of Levene's Statistic is 0.012 less than 0.05 so Anova table will be used. there is no signifiant difference between the number of actual birds, predicted number of birds using Malthus Model and predicted number of birds using Verhulst Model since the significant level of the Anova table is 0.244 greater than 0.05 and this confirm the Turkey HSO results of(multiple comparison).

\section{CONCLUSION}

In this work we may conclude that either of the two models can be use for prediction of birds population, since we do not find the significance difference between the observe and predicted number of birds using the two models after subjecting the result into statistical test of significance of independence t-test as well as one-way Anova.

Kingsland Sharon- Modeling Nature: Episodes in the History of Population Ecology, University of Chicago Press, (1995), 127 - 146.

Renshaw Eric -Modeling Biological Population in space and Time, Cambridge University Press, (1991), 6-9.

McIntosh Robert -The background of Ecology, Cambridge, University Press, (1985), 171 198.

Montgomery D.C- design and analysis of experiment, John Wiley and sons, New York, (1997)

Udom A.U-Essential of Statistic, Louis Chumez Primary Enterprises, Nsukka Nigeria, (2011).

R. Pearl-The growth of Population, Quart. Rev. Biol.2, (1927), 532.

W. C. Allee-The Social Life of animals, W. W Norton and Co. New York (1938) 